\title{
Bioactive oligomers from natural polyhydroxyalkanoates and their synthetic analogues
}

\author{
Grażyna Adamus' ${ }^{1)}$, Piotr Kurcok1), Iza Radecka ${ }^{2)}$, Marek Kowalczuk ${ }^{1), 2), *)}$ \\ DOI: dx.doi.org/10.14314/polimery.2017.317
}

\begin{abstract}
This publication is dedicated to the memory of the scientist and friend Prof. Andrzej Duda
\end{abstract}

\begin{abstract}
Contemporary reports on the bioactive oligomers derived from natural aliphatic co-polyesters (PHA) and their synthetic analogues, formed through anionic ring-opening polymerization (ROP) of $\beta$-substituted $\beta$-lactones are presented. Synthetic routes for such oligomers, developed mostly by Polish authors, are discussed. The described approaches enable design of novel biodegradable and bioactive oligomers for diverse applications in medicine, cosmetic industry and agrochemistry.
\end{abstract}

Keywords: aliphatic polyester, anionic polymerization, bioactive oligomer, $\beta$-substituted $\beta$-lactone.

\section{Otrzymywanie bioaktywnych oligomerów z naturalnych biopoliestrów i ich syntetycznych analogów}

Streszczenie: Przedstawiono przegląd aktualnych wyników badań dotyczących bioaktywnych oligomerów otrzymywanych z naturalnych alifatycznych ko-poliestrów (PHA) oraz ich syntetycznych analogów, uzyskanych na drodze anionowej polimeryzacji z otwarciem pierścienia (ROP) $\beta$-podstawionych $\beta$-laktonów. Omówiono ścieżki syntezy tych oligomerów opracowane głównie przez polskich badaczy. Zaprezentowane metody umożliwiaja projektowanie nowych biodegradowalnych, a zarazem bioaktywnych oligomerów mogących znaleźć różnorodne zastosowania w medycynie, przemyśle kosmetycznym i agrochemii.

Słowa kluczowe: poliester alifatyczny, anionowa polimeryzacja, oligomer bioaktywny, $\beta$-podstawiony $\beta$-lakton.

Polyhydroxyalkanoates (PHA) are a group of biopolyesters that have a wide range of applications. Extensive progress has been made in our understanding of PHA biosynthesis, and currently, it is possible to engineer bacterial strains to produce PHA with desired properties. Overview on the current carbon sources used for PHA production and the methods used to transform these sources into fermentable forms has been published recently [1]. It should be mentioned, that among various carbons sources we report also on the ability of bacteria to produce PHA from polyethylene via oxidized polyethylene wax as a novel carbon source [2]. The studies are also carried out by other laboratories on production of high levels of PHA in tobacco plants [3].

\footnotetext{
1) Centre of Polymer and Carbon Materials, Polish Academy of Sciences, 34 M. Curie-Skłodowskiej St., 41-119 Zabrze, Poland.

2) University of Wolverhampton, Faculty of Science and Engineering, School of Biology, Chemistry and Forensic Science, Wulfuna Street, Wolverhampton WV1 1LY, UK.

*) Author for correspondence; e-mail: marek.kowalczuk@ cmpw-pan.edu.pl
}

PHA polymers are thermoplastic and depending on their chemical composition they may differ in their properties. Blending of PHA with other biodegradable polymers tunes properties of polymeric materials suitable for packaging applications. Current trends in the packaging industry are towards compostable bio-based lighter weight materials for reduction of raw material use, transportation costs, minimizing the amount of waste and it may be expected that interest in sustainable materials combined with barrier improving additives will continue to growth [4].

\section{OLIGOMERS FROM NATURAL POLYHYDROXYALKANOATES}

PHA due to their in vivo and in vitro biodegradation as well as cell and tissue compatibility can be used for medical applications, especially as implants, including heart valve tissue engineering, vascular tissue engineering, bone tissue engineering, cartilage tissue engineering as well as nerve conduit tissue engineering. Moreover, PHA implants were found not to cause carcinogenesis during long-term implantation. Chemical modifications of PHA 


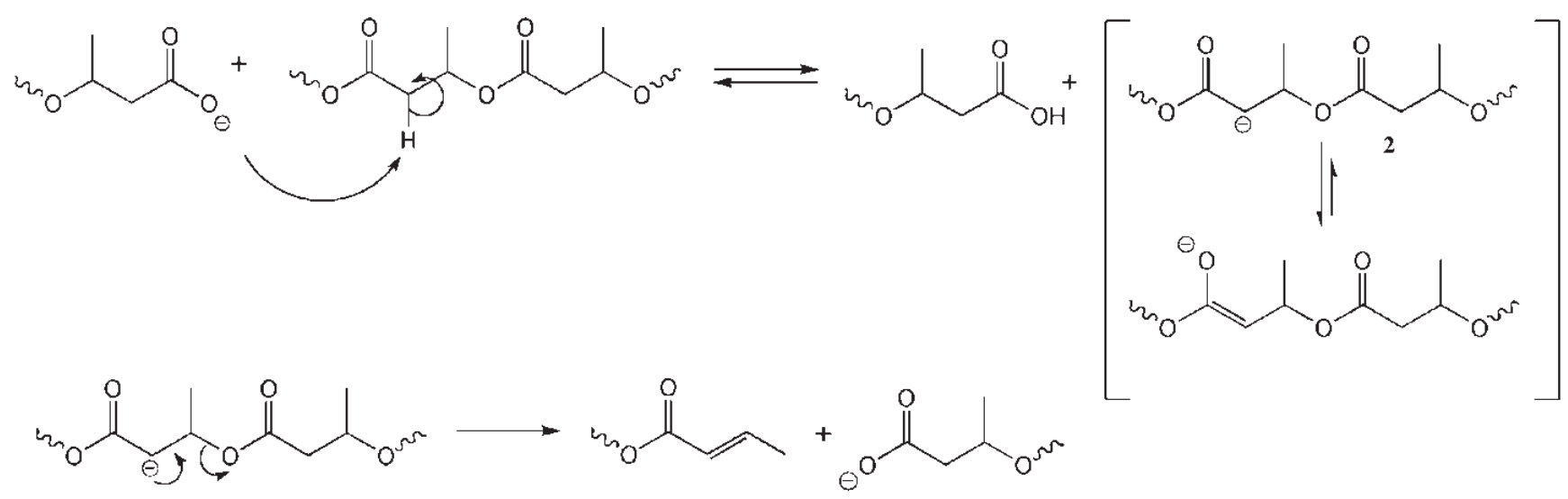

Scheme A<smiles>[Y]OC(=O)CC(C)(C)OC(=O)CC(C)(C)OC(=O)/C=C/C</smiles>

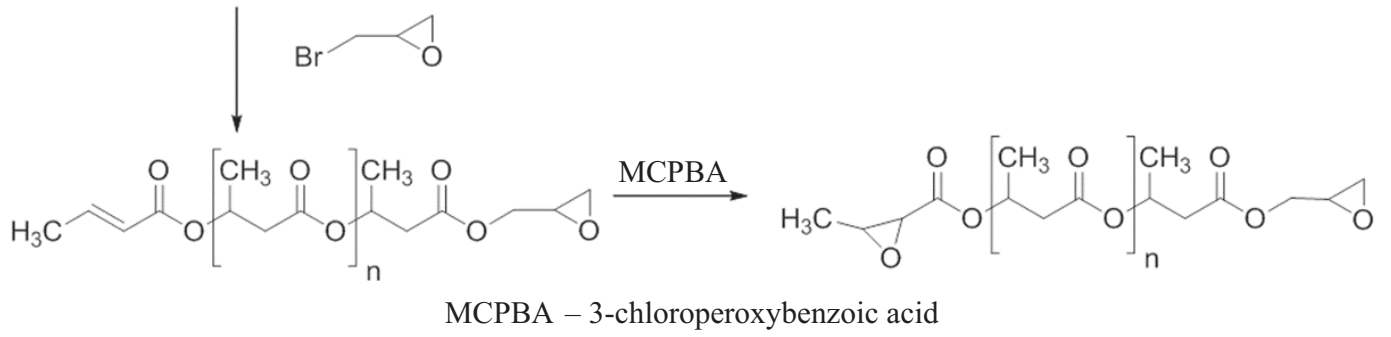

Scheme B

Scheme C

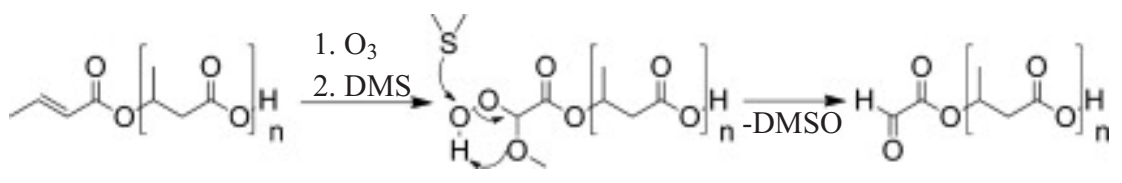

in order to introduce functional groups, that cannot be easily achieved by bioconversion processes, are a valuable challenge since chemically modified PHA can be utilized as multifunctional biomaterials [5].

\section{PHA oligomers contained unsaturated end groups}

PHA can be reacted with a carbonate salts, yielding oligomers possessing a controlled molecular weight, which can be modulated in view of the specific application for which the products are intended [6-8]. The degradation reaction can be carried out as a continuous process, e.g., by means of an extruder, with outstanding advantages for an industrial applications. The obtained oligomers are terminated by unsaturated and carboxylate end groups [as revealed by electrospray ionization mass spectrometry (ESI-MS ${ }^{n}$ ) analyses]. They are formed according to E1cB elimination reaction mechanism of $\alpha$-deprotonation of poly(3-hydroxyalkanoate)s, in the intermolecular process. The process of carboxylate induced degradation of PHA is shown in Scheme A [9].
The unsaturated end groups can be subjected to subsequent modifications to obtain a wide variety of functional end groups, for instance hydroxyl, carboxyl or oxirane groups by oxidation of the above double bonds [10]. As example the synthesis of epoxy-functionalized oligo(3-hydroxybutyrate) $(\mathrm{OHB})$ is presented in Scheme B.

Such unsaturated end groups of $\mathrm{OHB}$ may be also ozonolyzed to the aldehyde function and used as PHA-based carriers for drug delivery systems with $\mathrm{pH}$-controlled release [11]. The example of such reaction can be synthesis of oligo(3-hydroxybutyrate) glyoxylate shown in Scheme C.

The controlled molecular weight and the presence of double bonds and/or other functional groups as terminal groups make the above oligomers or polymers particularly suitable as macromers (building blocks) for the synthesis and/or modification of polymers, particularly of biodegradable polymers for medical applications [12]. It was also found that oligomers consisted of 3-hydroxybutyrate 3-malic acid units can be synthesized via thermal treatment of poly(3-hydroxybutyrate) (PHB) in oxygen/ ozone mixture. Nuclear magnetic resonance (NMR) and 
multi-stage mass-spectrometry (MS) characterization revealed random distribution of 3-malic acid units in oligomeric products as well as content of the malic acid units dependent on oxidation conditions [13].

\section{PHA oligomers contained hydroxyl end groups}

A highly selective method for controlling the degradation of PHA via a reduction reaction that uses lithium borohydride was reported [14]. Using this method, oligo(hydroxyalkanoate)diols were obtained according reaction shown in Scheme D.

The structural characterization of the oligo(hydroxyalkanoate)diols was conducted using NMR and ESI-MS ${ }^{\mathrm{n}}$ analyses, which confirmed that oligomers were terminated by two hydroxyl end groups. The reduction of the PHA occurred in a statistical way regardless of the chemical structure of the comonomer units or of the microstructure of the polyester chain. This method can be used to synthesize various PHA oligodiols that are potentially useful in the further synthesis of tailor-made biodegradable materials for medical applications.

\section{PHA bioactive oligomers}

The transesterification of PHA has been used as a tool for the preparation of delivery systems for selected bioac- tive compounds containing either carboxyl or hydroxyl functionalities [15]. The first synthetic strategy was designed for bioactive compounds within the carboxyl group, and these conjugates were obtained through the transesterification of natural PHA. Scheme E shows transesterification reaction of PHA by (4-chloro-2-methylphenoxy)acetic acid (MCPA).

The second synthetic strategy was selected for bioactive compounds within the hydroxyl group [16]. The tyrosol-polymer conjugates were synthesized via transesterification reaction of tyrosol with selected PHA, presented in Scheme F.

The transesterification reaction of PHA with a bioactive compounds constitutes simple and economically favorable method for obtaining such conjugates. The bioactive PHA oligomers may be used in the area of controlled delivery systems in medicine, agrochemistry, in the cosmetic industry, in household products and in coating systems.

\section{BIOACTIVE OLIGOMERS FROM SYNTHETIC ANALOGUES OF POLYHYDROXYALKANOATES}

\section{Bioactive oligomers of PHB analogue}

Developed at our laboratories, and independently confirmed by Duda the anionic ring-opening polymerization (ROP) of $\beta$-substituted $\beta$-lactones seems to be a perfect

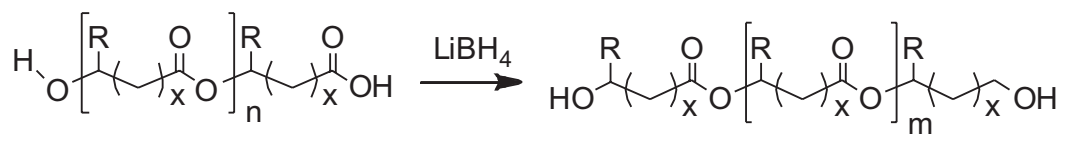

Scheme D<smiles>[R]C(O)C(C)(C)CC(C)(C)C(=O)OC(C)(C)C</smiles><smiles>Cc1cc(Cl)ccc1OCC(=O)O</smiles>

Scheme E<smiles>[R]C1CC(C)(O)C(C)(CC([Y])(C)C(=O)OC([2H])([2H])C)C1(C)C</smiles><smiles>[R]C(CC(C)(C)C([R])(C)OC(=O)COc1ccc(Cl)cc1C)C(=O)OC([2H])([2H])[2H]</smiles>

$\mathrm{R}=\mathrm{CH}_{3}, \mathrm{x}=3 \mathrm{HB}$ units

or $\mathrm{R}=\mathrm{H}, \mathrm{x}=4 \mathrm{HB}$ units

4-toluenesulfonic acid monohydrate $158-163{ }^{\circ} \mathrm{C}$

$$
\text { (n) }
$$$$
\mathrm{R}=\mathrm{H}, \mathrm{x}=4 \mathrm{HB} \text { units }
$$ 
tool for the preparation of PHA analogues with the desired molecular structure, including the structure of the end groups [17-19]. In contrast to unsubstantiated four membered $\beta$-propiolactone, $\beta$-butyrolactone (BL) is not polymerized by common anionic initiators. However, these initiators, when activated by the addition of macrocyclic ligands such as crown ethers or cryptands, are able to initiate the polymerization of $\mathrm{BL}$ to $\mathrm{PHB}$, i.e., the simplest PHA analogue [20, 21]. The same effect may be achieved by using bulky counterions or suitable highly polar aprotic solvents, e.g., DMSO [22, 23]. The polymer chain growth proceeds regioselectively and stereoselectively entirely via carboxylate anions [24]. The anionic ROP reaction of BL to PHB is shown in Scheme G.

Propagation on carboxylate active centers (much less sensitive to impurities than any other anionic species) enables the scaling up of the anionic ROP polymerization process $[25,26]$.

Also other catalysts were used for ROP reaction of $\mathrm{BL}$, including discrete rare earth and cationic systems [27-30].

Synthetically prepared OHB were found to be nontoxic and they may be used as carriers covalently bounded to suitable bioactive compounds [31]. In our studies regarding this area, several bioactive PHB oligomers suitable for medical, cosmetic, agrichemical and functional packaging applications have been prepared and characterized at the molecular level using the ESI-MS ${ }^{n}$ technique. The drug delivery systems were focused on penicillin $\mathrm{G}$, acetylsalicylic acid, and ibuprofen [32-34]. For perspective applications in cosmetology the OHB conjugates with $\alpha$-lipoic acid (LA), $p$-coumaric acid, $p$-anisic acid (AA) and vanillic acid (VA) have been obtained and characterized $[35,36]$. Synthetic pathway to OHB conjugate with selected antioxidants (AA and VA) is shown in Scheme $\mathrm{H}$.

The bioconjugate hydrolytic degradation studies allowed gaining thorough insight into the hydrolysis process and confirmed the release of bioactive species. In vitro studies demonstrated that all of the conjugates studied were well tolerated by $\mathrm{KB}$ and $\mathrm{HaCaT}$ cell lines, as they had no marked cytotoxicity, while conjugates with a relatively short OHB carrier are optimal to support keratinocyte function [37].

For potential agricultural applications novel phenoxycarboxylic acid-OHB conjugates have been synthetized, and OHB conjugates with sorbic acid and benzoic acid, designed for food active packaging systems, have been also reported and the structures of the resulting conjugates have been established at the molecular level by electrospray ionization multi-stage mass spectrometry [38]. The same strategy has also been applied for the synthesis and characterization of a novel polypyrrole material grafted with biodegradable $\mathrm{OHB}$ pendants. The obtained OHB functionalized pyrroles were found to be promising candidates for the preparation of biodegradable conductive polymers $[39,40]$.

\section{Bioactive oligomers of PHA analogues}

The specific synthetic method based on the carbonylation of the respective epoxides under $\mathrm{CO}$ at ambient pres-

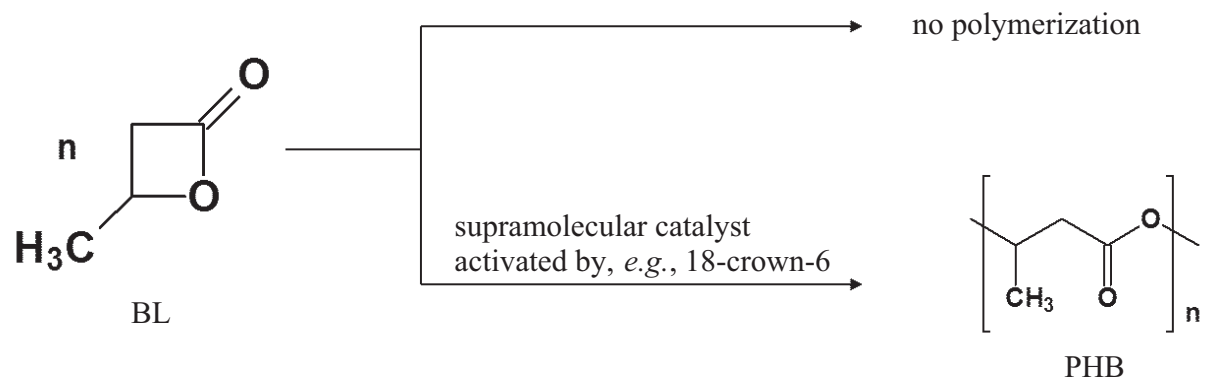

Scheme G

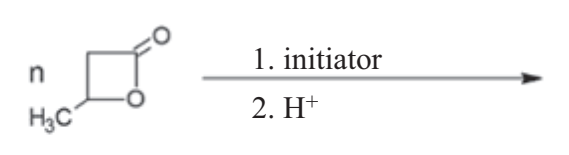

initiator: $\mathrm{RK}^{+}$or $\mathrm{RNa}^{+}$

$$
\mathrm{R} \text { : }
$$<smiles>[R]OC(=O)c1ccc(OC)cc1</smiles><smiles>COc1cc(C(=O)[O-])ccc1O</smiles><smiles>[R]C(C)CC(=O)O[GaH]</smiles>

main product: p-AA-OHB conjugate or VA-OHB conjugate side product 


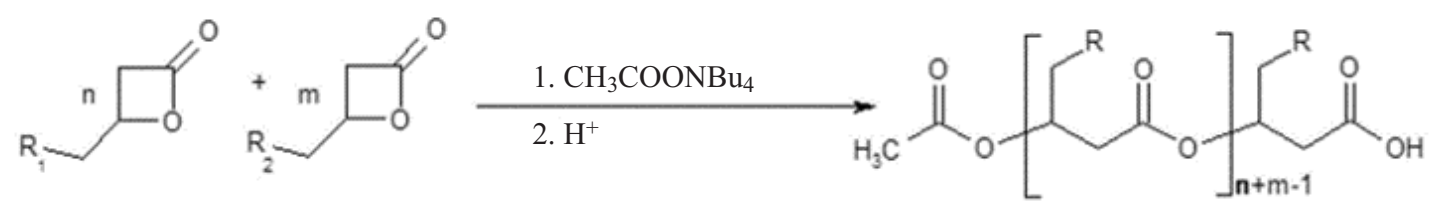

$\mathrm{R}_{1}=\mathrm{H}$ or $\mathrm{R}_{2}$<smiles>[R][R]=CC(C)c1ccc(CC(C)C)cc1</smiles><smiles>COC(=O)COc1ccc(Cl)cc1C</smiles>

or<smiles>COC(=O)c1ccccc1</smiles><smiles>COC(=O)c1ccc(OC)cc1</smiles>

Scheme I

sure opens up new opportunities for exploring the utility of $\beta$-lactones (and in particular precursors of synthetic analogues of natural PHA, i.e., $\beta$-substituted $\beta$-lactones) as monomers for the synthesis of new polymers with desired properties. Thus, block and random synthetic PHA copolymers were prepared by anionic ROP [41-43].

Incorporation of bioactive compounds into the $\beta$-lactones structure may lead to homo- and co-oligoesters with a bioactive moiety covalently linked as pendent groups along an oligomer backbone. This synthetic strategy was applied by us for preparation of the PHA synthetic analogues with ibuprofen pendant groups [44], pesticide moieties [45] and recently antioxidants used in cosmetics [46]. The respective synthetic pathway, presented on Scheme I shows synthesis of bioactive co-oligoesters via copolymerization of BL with $\beta$-substituted $\beta$-lactones containing covalently bonded selected bioactive moieties [e.g., ibuprofen, (4-chloro-2-methylphenoxy)acetic acid, and anisic acid].

Novel delivery systems obtained via the elaborated synthetic strategy contain a larger loading of biologically active substances per polymer macromolecule and their amount as well as position at the (co)polymer chain can be controlled.

\section{CONCLUSIONS}

Biodegradable polymers have become materials of hope for the future and knowledge on the relationships between their structure, properties, and function is essential for prospective safe applications of such materials in the areas of human health and the environment.

When the development of biodegradable polymers was in its infancy the most crucial features were concentrated on the effect of macromolecular architecture, new monomer systems, polymerization mechanisms, and different polymerization techniques on final biodegradable properties. Significant efforts have been directed towards specific areas, such as mechanisms of biodegradation, biocompatibility and processing conditions. However, especially for potential applications in medicine such aspects like bio-safety of biodegradable polymers or nano-safety of their composites were and still are frequently neglected. The diverse applications of biodegradable polymers require case specific characterization and optimization of the material properties, its preparation, processing, and recycling. Pulling these different elements together under the common thread of forensic engineering of advanced polymeric materials (FEAPM) provides a central driving force for the otherwise disconnected works and constitutes the novelty of our recent research [47]. Such an approach helps to design novel biodegradable polymeric materials and to avoid failures of the commercial products manufactured from them.

This work was supported by the National Science Centre projects: DEC-2012/07/B/ST5/00627 (MK), UMO-2013/11/B/ST5/02222 (GA), 2015/17/B/ST5/01086 (PK) and by the European Regional Development Fund: contract No. POIG.01.03.01-00-018/08. The outcomes of this research will be used to implement the UE PLASTiCE project (3CE368P1, "Innovation value chain development for sustainable plastics in Central Europe", CENTRAL EUROPE Programme, cofinanced by ERDF.

\section{REFERENCES}

[1] Jiang G., Hill D.J., Kowalczuk M. et al.: International Journal of Molecular Sciences 2016, 17, 1157. http://dx.doi.org/10.3390/ijms17071157

[2] Radecka I., Irorere V., Jiang G. et al.: Materials 2016, 9, 367. http://dx.doi.org/10.3390/ma9050367

[3] Bohmert-Tatarev K., McAvoy S., Daughtry S. et al.: Plant Physiology 2011, 155, 1690. http://dx.doi.org/10.1104/pp.110.169581

[4] Bugnicourt E., Cinelli P., Lazzeri A. et al.: eXPRESS Polymer 
Letters 2014, 8, 791.

http://dx.doi.org/10.3144/expresspolymlett.2014.82

[5] Kai D., Loh X.J.: ACS Sustainable Chemistry and Engineering 2014, 2, 106. http://dx.doi.org/10.1021/sc400340p

[6] Kawalec M., Sobota M., Scandola M. et al.: Journal of Polymer Science Part A: Polymer Chemistry 2010, 48, 5490. http://dx.doi.org/10.1002/pola.24357

[7] Eur. Pat. EP 2346922 (2014).

[8] Kwiecień M., Kawalec M., Kurcok P. et al.: Polymer Degradation \& Stability 2014, 110, 71.

http://dx.doi.org/10.1016/j.polymdegradstab.2014.07.028

[9] Kawalec M., Adamus G., Kurcok P. et al.: Biomacromolecules 2007, 8, 1053. http://dx.doi.org/10.1021/bm061155n

[10] Michalak M., Kawalec M., Kurcok P.: Polymer Degradation \& Stability 2012, 97, 1861.

http://dx.doi.org/10.1016/j.polymdegradstab.2012.05.007

[11] Michalak M., Marek A., Zawadiak J. et al.: European Polymer Journal 2013, 49, 4149.

http://dx.doi.org/10.1016/j.eurpolymj.2013.09.021

[12] Adamus G., Sikorska W., Janeczek H. et al.: European Polymer Journal 2012, 48, 621. http://dx.doi.org/10.1016/j.eurpolymj.2011.12.017

[13] Michalak M., Kwiecień M., Kawalec M. et al.: RCS Advances 2016, 6, 12 809. http://dx.doi.org/10.1039/c5ra27041c

[14] Kwiecień M., Adamus G., Kowalczuk M.: Biomacromolecules 2013, 14, 1181.

http://dx.doi.org/10.1021/bm400141s

[15] Kwiecień I., Radecka I., Kowalczuk M. et al.: PLoS ONE 2015, 10, e0120149.

http://dx.doi.org/10.1371/journal.pone.0120149

[16] Kwiecień I., Radecka I., Kwiecień M. et al.: Materials 2016, 9, 307. http://dx.doi.org/10.3390/ma9050307

[17] Jedliński Z., Kowalczuk M., Główkowski W. et al.: Macromolecules 1991, 24, 349. http://dx.doi.org/10.1021/ma00002a002

[18] Duda A.: Journal of Polymer Science Part A: Polymer Chemistry 1992, 30, 21. http://dx.doi.org/10.1002/pola.1992.080300103

[19] Adamus G., Kowalczuk M.: Biomacromolecules 2008, 9, 696. http://dx.doi.org/10.1021/bm701077v

[20] Kawalec M., Śmiga-Matuszowicz M., Kurcok P.: European Polymer Journal 2008, 44, 3556. http://dx.doi.org/10.1016/j.eurpolymj.2008.09.008

[21] Jedliński Z., Kurcok P., Lenz R.W.: Macromolecules 1998, 31, 6718. http://dx.doi.org/10.1021/ma980663p

[22] Kurcok P., Śmiga M., Jedliński Z.: Journal of Polymer Science Part A: Polymer Chemistry 2002, 40, 2184. http://dx.doi.org/10.1002/pola.10285

[23] Juzwa M., Jedliński Z.: Macromolecules 2006, 39, 4627. http://dx.doi.org/10.1021/ma0602369

[24] Jedliński Z., Kowalczuk M., Kurcok P. et al.: Macromolecules 1996, 29, 3773. http://dx.doi.org/10.1021/ma951888s

[25] Kowalczuk M.: Polymer Science Series 2009, A 51, 1229. http://dx.doi.org/10.1134/S0965545X09110078

[26] Kawalec M., Coulembier O., Gerbaux P. et al.: Reactive \& Functional Polymers 2012, 72, 509.

http://dx.doi.org/10.1016/j.reactfunctpolym.2012.04.013

[27] Carpentier J.: Macromolecular Rapid Communications 2010,
31, 1696. http://dx.doi.org/10.1002/marc.201000114

[28] Basko M., Duda A., Kazmierski S. et al.: Journal of Polymer Science, Part A: Polymer Chemistry 2013, 51, 4873. http://dx.doi.org/10.1002/pola.26916

[29] Dove A.P.: Chemical Communications 2008, 6446. http://dx.doi.org/10.1039/B813059K

[30] Guillaume S.M., Annunziata L., del Rosal I. et al.: Polymer Chemistry 2013, 4, 3077. http://dx.doi.org/10.1039/C3PY00056G

[31] Piddubnyak V., Kurcok P., Matuszowicz A. et al.: Biomaterials 2004, 25, 5271. http://dx.doi.org/10.1016/j.biomaterials.2003.12.029

[32] Adamus G., Kowalczuk M.: Rapid Communications in Mass Spectrometry 2000, 14, 195.

h t t p : / / d x.d o i o r g / 10.1002 / ( S I C I ) 1097 0231(20000229)14:4<195::AID-RCM864>3.0.CO;2-X

[33] Juzwa M., Rusin A., Zawidlak-Węgrzyńska B. et al.: European Journal of Medicinal Chemistry 2008, 43, 1785. http://dx.doi.org/10.1016/j.ejmech.2007.11.004

[34] Zawidlak-Węgrzyńska B., Kawalec M., Bosek I. et al.: European Journal of Medicinal Chemistry 2010, 45, 1833. http://dx.doi.org/10.1016/j.ejmech.2010.01.020

[35] Maksymiak M., Kowalczuk M., Adamus G.: International Journal of Mass Spectrometry 2014, 359, 6. http://dx.doi.org/10.1016/j.ijms.2013.11.009

[36] Maksymiak M., Dębowska R., Jelonek K.: Rapid Communications in Mass Spectrometry 2013, 27, 773. http://dx.doi.org/10.1002/rcm.6509

[37] Maksymiak M., Dębowska R., Bazela K. et al.: Biomacromolecules 2015, 16, 3603. http://dx.doi.org/10.1021/acs.biomac.5b01065

[38] Kwiecień I., Adamus G., Bartkowiak A. et al.: Designed Monomers \& Polymers 2013, 17, 311. http://dx.doi.org/10.1080/15685551.2013.840505

[39] Domagała A., Maksymiak M., Janeczek H. et al.: Journal of Material Science 2014, 49 (14), 5227. http://dx.doi.org/10.1007/s10853-014-8241-0

[40] Domagała A., Domagała W., Ledwoń P. et al.: Polymer International 2016, 65, 1395. http://dx.doi.org/10.1002/pi.5190

[41] Jedliński Z., Kowalczuk M., Kurcok P. et al.: Makromolekulare Chemie 1987, 188, 1575. http://dx.doi.org/10.1002/macp.1987.021880704

[42] Adamus G.: Macromolecules 2009, 42, 4547. http://dx.doi.org/10.1021/ma900349u

[43] Adamus G., Kwiecień I., Maksymiak M. et al.: Analytica Chimica Acta 2014, 808, 104. http://dx.doi.org/10.1016/j.aca.2013.09.001

[44] Pol. Pat. App. P-409 509 (2014).

[45] Kwiecień I., Bałakier T., Jurczak J. et al.: Rapid Communications in Mass Spectrometry 2015, 29, 533. http://dx.doi.org/10.1002/rcm.7133

[46] Maksymiak M., Bałakier T., Jurczak J. et al.: RSC Advances 2016, 6, 57 751. http://dx.doi.org/10.1039/c6ra09870c

[47] Sikorska W., Adamus G., Dobrzyński P. et al.: Polymer Degradation and Stability 2014, 110, 518. http://dx.doi.org/10.1016/j.polymdegradstab.2014.09.019 